\title{
TRANSOBTURATOR TAPE FOR THE TREATMENT OF STRESS URINARY INCONTINENCE IN A SMALL MUNICIPAL HOSPITAL: A SINGLE SURGEON EXPERIENCE
}

\author{
Srbobran Branković1, Ivan Ignjatović2 ${ }^{2,3}$ Bojan Jovanović4
}

\begin{abstract}
The aim of the study was to describe a study of 43 patients operated using a transobturator tape (TOT). A prospective study was performed on forty free patients operated between 2014 and 2020. In all patients, the diagnosis of stress urinary incontinence (SUI) was based on clinical criteria: positive stress test or positive pad test, confirmed urethral hypermobility (> 30 degrees), ultrasound and bladder diary for three days. Cystoscopy was performed in all patients to document satisfactory bladder compliance and capacity, and to exclude ordinary pathology of the bladder. In all patients, TOT was performed. Follow up was performed one month, six months, and 12 months after the surgery. All patients, 42/43 $(97.6 \%)$, were in a generally good preoperative health state according to American Society of Anesthesia grading system (ASA 1-2). The subjective cure was achieved in 36/43 (83.7\%) patients after one year. The objective cure was achieved in $32 / 43(74.7 \%)$ patients after one year. OAB was present preoperatively in $19 / 43(44.1 \%)$ patients, and postoperatively in $9 / 43$ $(20.9 \%)$ patients $(p<0.02)$. Postoperative complications were minor (Clavien-Dindo grade $\leq$ 2 ) in $42 / 43(97.6 \%)$ patients. Transobturator tape can be successfully performed in selected patients in a small municipal hospital.
\end{abstract}

Acta Medica Medianae 2021;60(1):68-73.

Key words: transobturator tape, incontinence, treatment

\footnotetext{
${ }^{1}$ Municipal Hospital Aleksinac, Aleksinac, Serbia

2University of Niš, Faculty of Medicine, Niš, Serbia

${ }^{3}$ Clinical Center Niš, Clinic for Urology, Niš, Serbia

${ }^{4}$ Center for Minimally Invasive Surgery, University Clinical

Center Niš, Niš, Serbia
}

Contact: Ivan Ignjatović

48 Dr Zoran Djindjić Blvd., 18000 Niš, Serbia

E-mail: ivanig@live.com

\section{Introduction}

Urinary incontinence is a common problem in females, which strongly affects their health state, emotional, and social life. It appears in form of stress urinary incontinence (SUI), urgent urinary incontinence, or mixed urinary incontinence in $49 \%$, $21 \%$, and $29 \%$ respectively (1).

Continence in females is based on the functional neural, muscular, and connective tissue integrity of the pelvic floor. Appearance of SUI is based on insufficient urethral support and urethral hypermobility. Consequently, temporary urethral incompetence appears, during the physical efforts, coughing, or heavy lifting with the clinical presentation of SUI (2).
Although the treatment of SUI is multimodal, surgical treatment is the most important and the most effective. Standard operation of SUI (Burch) was dominantly replaced by tension-free vaginal tape (TVT) introduced by Papa Petros and UIf Ulmsten (3). However, although the TVT procedure is safe and efficient, serious complications and even four deaths were reported (4). Further simplification of the procedure, transobturator tape (TOT) was introduced by Delorme (5). It made the procedure safe and easy, convenient to perform in a small municipal hospital by a single urological surgeon.

\section{Materials and methods}

A total of forty free patients operated between 2014 and 2019 available for the one year follow-up were included in a prospective study. In all patients, standard diagnostic examinations were performed: positive stress test or positive 20' pad test, confirmed urethral hypermobility (> 30 degrees), ultrasound which confirmed normal anatomy and bladder capacity and no residual urine. A bladder diary was done for three days. Cystoscopy was performed in all patients to document satisfactory bladder compliance and capacity and to exclude ordinary pathology of the bladder. In four patients, a cystocele grade 2 was present (Baden- 
Walker). Other patients were without significant pelvic organ prolapse.

Overactive bladder (OAB) syndrome was defined when more than eight voidings/24 hours were found according to the bladder dairy, as well as, episodes of urgency with or without urgency incontinence (6). In all patients, preoperative normal vaginal smear findings and sterile urine were confirmed before the surgery.

The procedure was performed using standard industrial tapes: T sling (Herniamesh, Torino, Italy), Aris (Coloplast, Italy) or Obtryx (Boston Scientific, USA) sling. The procedure was performed "outsidein" (5). Cystocele was repaired in four patients using a natural tissue repair. Intraoperative and postoperative complications were recorded and classified according to the Clavien-Dindo scale of surgical complications severity (7). Postoperative follow-ups were performed after one, six, and 12 months. The objective outcome was evaluated as cure (negative stress test, or negative $20^{\prime}$ pad test) objective improvement ( $>50 \%$ reduction of leakage at 20 minutes pad test, with a minimally positive stress test), or failure (positive stress test, or pad test). The subjective cure was defined as no loss of urine with usual exercise or coughing and significant improvement of the overall health state, so the surgery was considered as worthwhile by the patient. Persistent urine loss at the same amount or with the minimal difference compared with the preoperative values was considered as a failure. Overall health state was evaluated in all patients according to internationally recognized ASA score (8). Statistics were performed by Chi-square test.

\section{Results}

Preoperative basic data about patients are shown in Table 1 . The majority of patients were postmenopausal, overweight or obese, without or with mild systemic disease (ASA 1-2). Mean Body Mass Index (BMI) was 28.4 (normal BMI is $\leq 25$ ). In the majority of patients, i.e., in $41 / 43$ (96.6\%) patients, there were no concomitant significant diseases (American Society of Anesthesiology ASA grade $1-2)$.

The outcome of the surgery is shown in Table 2. The subjective cure was achieved in $37 / 43$ (86\%) and remained in $36 / 43(83.7 \%)$ patients after one year. The objective cure was achieved in 33/43 (76.7\%) patients and remained in $32 / 43(74.7 \%)$ patients after one year.

Table 1. Basic data about patients

\begin{tabular}{|lc||}
\hline Patients data & No \\
\hline \hline Age & $62.3 \pm 12.2$ \\
Parity (mean \pm SD) & $1.7 \pm 0.6$ \\
BMI (mean \pm SD) & $28.4 \pm 1.7$ \\
Postmenopausal & $36(83.7 \%)$ \\
Previous gynecologic surgery & $11(25.5 \%)$ \\
Hospital stay (days, mean \pm SD) & $3.7 \pm 0.6$ \\
\hline \hline ASA score & \\
\hline \hline 1 & $20(46.5 \%)$ \\
2 & $21(48.8 \%)$ \\
3 & $2(4.6 \%)$ \\
\hline
\end{tabular}

Table 2. Outcome of surgery

\begin{tabular}{|l||c||c|c||}
\hline Objective outcome & $\begin{array}{c}\text { Postoperative } \\
1 \text { month }\end{array}$ & $\begin{array}{c}\text { Postoperative 6 } \\
\text { months }\end{array}$ & $\begin{array}{c}\text { Postoperative 12 } \\
\text { months }\end{array}$ \\
\hline \hline Cure & $33(76.7 \%)$ & $32(74.4 \%)$ & $32(74.4 \%)$ \\
Improvement & $7(16.3 \%)$ & $8(18.6 \%)$ & $8(18.6 \%)$ \\
Failure & $3(7 \%)$ & $3(7 \%)$ & $3(7 \%)$ \\
\hline \hline Subjective outcome & \multicolumn{3}{|c|}{} \\
\hline \hline Cure & $37(86 \%)$ & $36(83.7 \%)$ & $36(83.7 \%)$ \\
Improvement & $3(7 \%)$ & $4(9.3 \%)$ & $4(9.3 \%)$ \\
Failure & $3(7 \%)$ & $3(7 \%)$ & $3(7 \%)$ \\
\hline
\end{tabular}


OAB syndrome is shown in Graph 1. It was present preoperatively in $19 / 43(44.1 \%)$ patients, and postoperatively in $9 / 43(20.9 \%)$ ( $p<0.02)$. Complications and Clavien-Dindo classification of them are shown in Table 3. There was a single patient $(2.4 \%)$ with Clavien-Dindo grade 3 complication.

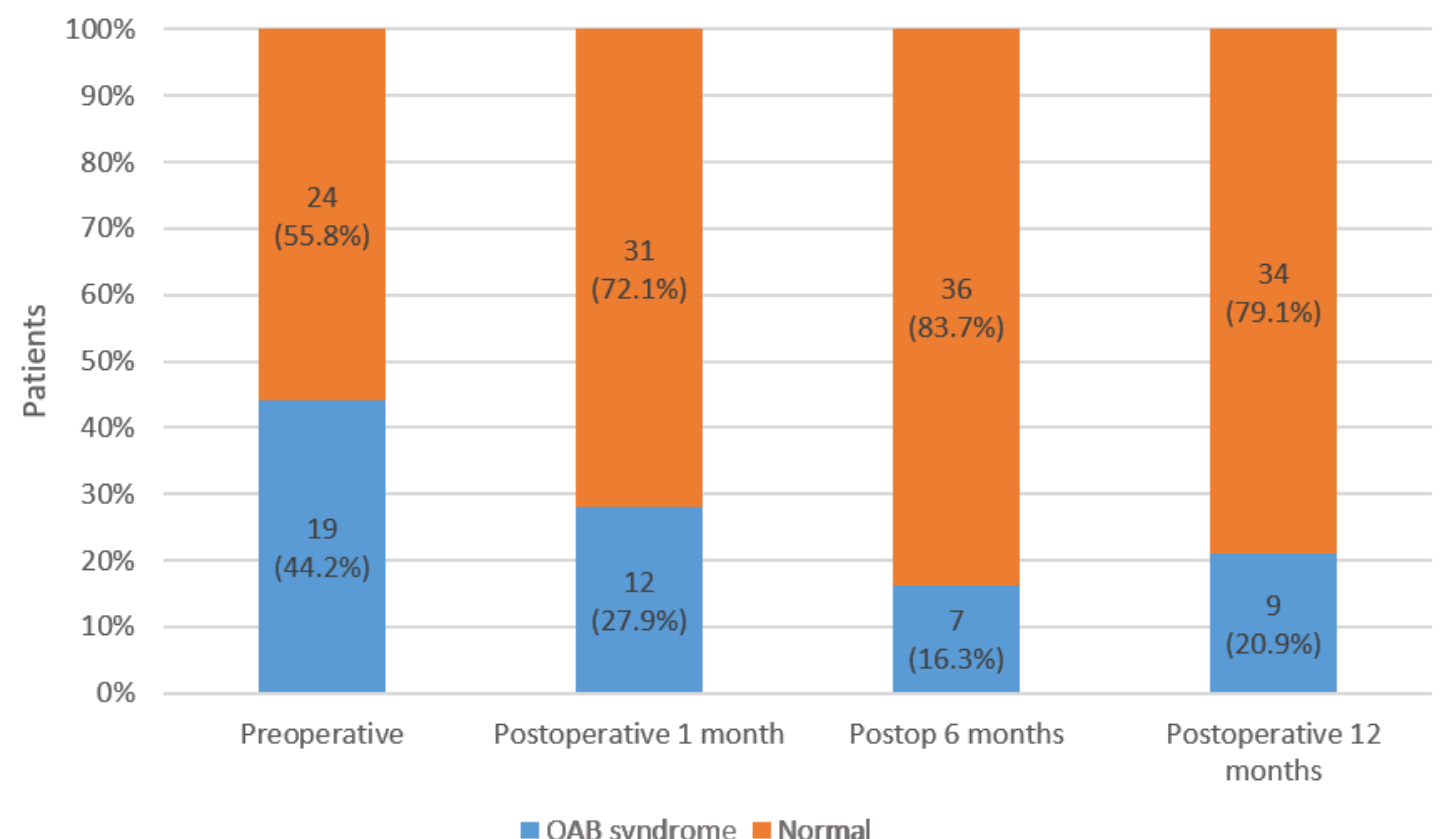

*preoperative -postoperative (12 months ) $p<0.02$

Graph 1. OAB syndrome before and after surgery

Table 3. Complications of surgery

\begin{tabular}{|llc||}
\hline Complication & No $(\%)$ & $\begin{array}{c}\text { Clavien-Dindo Complication } \\
\text { Severity Grade }\end{array}$ \\
\hline \hline Infection & $9 / 43(20.1 \%)$ & 2 \\
Regional hematoma & $6 / 43(13.9 \%)$ & 2 \\
Residual urine $(>50 \mathrm{ml})$ & $4 / 43(9.1 \%)$ & 3 \\
Exteriorization of the sling & $1 / 43(2.3 \%)$ & 2 \\
\hline
\end{tabular}

\section{Discussion}

Our results have confirmed that the treatment of TOT in a small municipal hospital is not inferior to the outcome in referral institutions published in the literature $(9,10)$.

Midurethral slings are now widely used in patients of almost all ages. However, failure rate increases with age with the reported subjective success rate of $91.0 \%, 80.6 \%, 66.7 \%$ and objective cure rates of $89.2 \%, 77.6 \%, 58.3 \%$ respectively, in ages less than 65 years, 66-75 years and older than 75 years (11). There is a higher risk of operative failure in patients with an increased BMI five years after surgery (12). The mean age of patients in our series is 62.3 which makes them the most suitable for incontinence surgery. The overall prevalence of overweight and obesity in the Serbian population is $57.4 \%$, especially at the age of $60-69$ years (13). Normal BMI should be surely considered as an "overselection". So, higher BMI than normal in older ages with SUI is expected according to a population 
features but only one extremely obese patient was operated, sadly without success.

Overall health state (ASA score) has a significant risk on perioperative morbidity (14). Our series of patients were without serious overall morbidity, and the incidence of postoperative complications was low. It also seems to contribute to the very good overall success.

European Association of Urology advises pure clinical diagnosis of SUI in uncomplicated cases, based on the positive stress test, proved urethral hypermobility, adequate bladder capacity and compliance based on bladder diary and absent residual urine on the standard bladder ultrasound (15). In our series of patients only "clear" cases were selected for the surgery, and because of that outcome is expected to be in line with the referral center.

There is a high diversity of the success interpretation. Absolute dryness is surely the strictest criterion and does not reflect the overall satisfaction of the patients. More acceptable, but also not ideal, is an improvement of more than $50 \%$ and the personal feeling that performing surgery was worthwhile for global health improvement. Very important for the personal experience of success are real expectations regarding the outcome of the surgery, and consequently careful preoperative counseling (16).

SUI affects different aspects of female life producing anxiety and depression, sexual function impairment, physical activity limitation, and even loss of independent living in the elderly (17). Because of that complete dryness is less important than the subjective outcome which reflects an overall improvement of the health. Overall impression of cure was present in $37 / 43(86.2 \%)$ of patients although less number of patients, 33/43 (76.7\%) were completely dry.

Complications after the surgery were minor (Clavien-Dindo grade 2) and solved medically. In one case, exteriorization of the sling was present (Clavien-Dindo grade 3) and the sling had been cut and the vagina sutured in local anesthesia three months after surgery without compromising continence.
OAB syndrome makes a significant deterioration of the quality of life. It is usually defined as the presence of frequency, urgency, or urinary incontinence together with SUI (18). It is a common problem among the aging female population especially among the patients with SUI, and in our patients as well. It was reduced after the surgery from $19 / 43(44.1 \%)$ to $9 / 43(20.9 \%)$ after the surgery. There were five patients $(11.6 \%)$ among them with de novo OAB syndrome. There are numerous reports about the curative role of TOT after surgery. The mechanism of cure remains unclear yet $(18,19)$. Although some things remained unsolved, the first recognizable source of $O A B$ was infection or obstruction caused by the sling $(18,19)$. In our patients, there were $4 / 43(9.3 \%)$ patients with more than $50 \mathrm{ml}$ of residual urine. In our study, postoperative infection was present in $9 / 43$ (20.1\%) of cases and effectively suppressed using targeted antibiotic therapy. It could be supposed that residual urine was non sensitive enough to exclude residual obstruction. The hospital stay was longer than usual. It was necessary to provide surveillance which was impossible outside the hospital ward. There are reports with a similar incidence of infection, and the most important risk factor is longer hospital stay, and readmission rate (20). Shortcomings of the study are that selection criteria were very strict and did not include a complete cohort of interested patients, so this type of medical service was not available for all patients with incontinence who required treatment. All patients were selected and controlled by the same surgeon which usually includes some amount of subjectivity. Evaluation of symptoms was performed on the most simplified clinical criteria instead of standardized validated questionnaires, making them less reliable. Strengths are, that this study confirms that TOT can be safely performed both in small and tertiary care centers, in the former, surely in a selected group of patients.

\section{Conclusion}

TOT can be safely performed in a municipal hospital. Selection criteria must be very strict for successful treatment. 


\section{References}

1. Hunskaar S, Burgio K, Diokno A, Herzog AR, Hjälmås $\mathrm{K}$, Lapitan MC. Epidemiology and natural history of urinary incontinence in women. Urology 2003;62(1): 16-23. [CrossRef] [PubMed]

2. Patel DA, Xu X, Thomason AD, Ransom SB, Ivy JS, DeLancey JO. Childbirthand pelvic floor dysfunction: an epidemiologic approach to the assessment of prevention opportunities at delivery. Am J Obstet Gynecol 2006;195:23-8. [CrossRef] [PubMed]

3. Ulmsten $U$, Petros $P$. Intravaginal slingplasty. An ambulatory surgical procedure for treatment of female urinary incontinence. Scand J Urol Nephrol 1995; 29:75-82. [CrossRef] [PubMed]

4. Hermieu JF. Complications de la technique TVT [Complications of the TVT technique]. Prog Urol 2003; 13:459-65. [PubMed]

5. Delorme E. La bandelette trans-obturatrice: un procédé mini-invasif pour traiter l'incontinence urinaire d'effort de la femme [Transobturator urethral suspension: mini-invasive procedure in the treatment of stress urinary incontinence in women]. Prog Urol 2001;11:1306-13. [PubMed]

6. Rovner ES, Gomes CM, Trigo-Rocha FE, Arap S, Wein AJ. Evaluation and treatment of the overactive bladder. Revista do Hospital das Clínicas 2002;57:3948. [CrossRef] [PubMed]

7. Dindo D, Demartines N, Clavien PA. Classification of surgical complications: a new proposal with evaluation in a cohort of 6336 patients and results of a survey. Ann Surg 2004;240:205-13. [CrossRef] [PubMed]

8. Committee on Economics. ASA Physical Status Classification System. Available from: URL: https://www.asahq.org/standards-and-guidelines/asaphysical-status-classification-system

9. Waltregny D, De Leval J. The TVT-obturator surgical procedure for the treatment of female stress urinary incontinence: a clinical update. Int Urogynecol J 2009; 20:337-48. [CrossRef] [PubMed]

10. Waltergny D, Gaspar Y, Reul O, Hamida W, Bonnet P, De leval J. TVTO for thetreatment of female stress urinary incontinence: results of a prospective study after 3 year minimum follow up. Eur Urol 2008;53: 401-10. [CrossRef] [PubMed]
11. Lo TS, Shailaja N, Tan YL, Wu MP, Chua S, Roy KW. Outcomes and failure risks in mid-urethral sling insertion in elderly and old age with urodynamic stress incontinence. Int Urogynecol J. 2020;31:717-26.

[CrossRef] [PubMed]

12. Laterza RM, Halpern K, Ulrich D, Graf A, Tamussino K, Umek W; Austrian TVT vs. TVT-O Study Group. Influence of age, BMI and parity on the success rate of midurethral slings for stress urinary incontinence. PLoS One 2018 Aug 16;13:e0201167. [CrossRef] [PubMed]

13. Grujić V, Cvejin MM, Nikolić EA, Dragnić N, Jovanović VM, Kvrgić S, Travar S. Association between obesity and socioeconomic factors and lifestyle. Vojnosanit Pregl 2009;66:705-10. [CrossRef] [PubMed]

14. Greer JA, Northington GM, Harvie HS, Segal S, Johnson JC, Arya LA. Functional status and postoperative morbidity in older women with prolapse. J Urol 2013;190:948-52. [CrossRef] [PubMed]

15. http://www.uroweb.org/guidelines/online-guidelines/

16. Rapp DE, Kobashi KC. Outcomes following sling surgery: importance of definition of success. J Urol 2008;180:998-1002. [CrossRef] [PubMed]

17. Farage MA, Miller $\mathrm{KW}$, Berardesca $\mathrm{E}$, Maibach $\mathrm{HI}$. Psychosocial and societal burden of incontinence in the aged population: a review. Arch Gynecol Obstet 2008; 277:285-90. [CrossRef] [PubMed]

18. Zyczynski HM, Albo ME, Goldman HB, Wai CY, Sirls LT, Brubaker L,et al. Change in Overactive Bladder Symptoms After Surgery for Stress Urinary Incontinence in Women. Obstet Gynecol 2015;126:423-30. [CrossRef] [PubMed]

19. Lee SK, Kang HW, Kim WT, Kim YJ, Yun SJ, Lee SC, et al. Impact of transobturator tape treatment on overactive bladder symptoms, particularly nocturia, in patients with mixed urinary incontinence. Korean ] Urol 2014;55:520-6. [CrossRef] [PubMed]

20. Weintraub AY, Reuven Y, Paz-Levy D, Yohay Z, Idan I, Elharar $D$, et al. Prevalence and risk factors for urinary tract infection up to one year following midurethral sling incontinence surgery. Eur J Obstet Gynecol Reprod Biol 2018;222:146-50. [CrossRef] [PubMed] 


\title{
TRANSOBTURATORNI TEJP U LEČENJU STRES URINARNE INKONTINENCIJE U MALOJ OPŠTINSKOJ BOLNICI - ISKUSTVA JEDNOG OPERATORA
}

\author{
Srbobran Branković ${ }^{1}$ Ivan Ignjatovićz, ${ }^{3}$, Bojan Jovanović 4 \\ ${ }^{1}$ Opšta bolnica Aleksinac, Aleksinac, Srbija \\ 2Univerzitet u Nišu, Medicinski fakultet, Niš, Srbija \\ ${ }^{3}$ Klinički centar Niš, Klinika za urologiju, Niš, Srbija \\ ${ }^{4}$ Centar za minimalno invazivnu hirurgiju, Univerzitetski klinički centar Niš, Niš, Srbija \\ Kontakt: Ivan Ignjatović \\ Bulevar dr Zorana Đinđića 48, 18000 Niš, Srbija \\ E-mail: ivanig@live.com
}

Zadatak istraživanja je prikaz prospektivne studije 43 slučaja operisana transopturatornim tejpom (TOT). Učinjena je prospektivna studija 43 bolesnice operisane između 2014. i 2020. godine, koje su imale najmanje jednogodišnje praćenje. Kod svih bolesnica, dijagnoza stres urinarne inkontinencije (SUI) zasnovana je na kliničkim parametrima: pozitivan stres test i $20^{\prime}$ pad test, potvrđena hipermobilnost uretre ( $\geq 30$ stepeni), ultrazvučni pregled i dnevnik mokrenja vođen najmanje tri dana. Cistoskopija je učinjena kod svih bolesnica da bi se potvrdili adekvatna distenzibilnost i kapacitet $\mathrm{i}$ isključila ostala oboljenja bešike. Sve bolesnice bile su u dobrom opštem zdravstvenom stanju, prema klasifikaciji Američkog anestezoiloškog udruženja (ASA 1-2). Subjektivno izlečenje postignuto je kod 36 bolesnica od 43 bolesnice (83,7\%), a objektivno izlečenje postignuto je kod 32 od $43(72,7 \%)$ bolesnice, nakon godinu dana. Sindrom hiperaktivne bešike (OAB) postojao je preoperativno kod 19 bolesnica od $43(44,1 \%)$ bolesnice, a kod 9 bolesnica od 43 bolesnice (20,9\%) postoperatovno $(p<0,02)$. Postoperativne komplikacije bile su lake kod 42 od $43(97,6 \%)$ bolesnice (Clavien Dindo grade $\leq 2$ ). TOT može da bude uspešno primenjivan i u malim opštinskim bolnicama, ukoliko se koriste strikni kriterijumi za odabir bolesnika.

Acta Medica Medianae 2021;60(1):68-73.

Ključne reči: transobturatorni tejp, inkontinencija, lečenje 